\section{The Importance of Corporate Governance of Banks Concerning the Ownership in the International Environment}

\author{
Mejra Festić \\ University of Maribor, Faculty of Economics and Business, Slovenia \\ mejra.festic@um.si \\ Polona Črepinko \\ Frankfurt, Germany \\ crepinko.polona@gmail.com

\section{Borut Bratina} \\ University of Maribor, Faculty of Economics and Business, Slovenia \\ borut.bratina@um.si
}

\begin{abstract}
The analysis of the factors of corporate governance is divided into four thematic sections. In the first part corporate governance is defined as part of the broader economic context. The second part deals with the principles of corporate governance. In the third part, the relation between the index of corporate governance and individual indicators (an indicator of commitment, transparency, and disclosure, caring for partners, and control and audit) regarding ownership is defined. An analysis was undertaken for the countries of Central and Eastern Europe. A higher level of foreign ownership had a positive correlation with the corporate governance index. On the other hand, the correlation between state ownership and corporate governance index was not clear. The prevention of poor banking practices does not only lie in controlling functions, but also in the general corporate and risk-taking cultures, and the social perception of managerial roles, regardless of ownership structure.
\end{abstract}

Keywords: corporate governance index, state ownership, ownership structure, corporate governance principles, board independence

\section{Introduction}

Sound corporate governance has become increasingly important since the economic and financial crisis that began in 2007, which exposed serious flaws in corporate governance. The crisis showed that the management tools were inefficient, especially when confronted with unexpected pressures and conflicts of interest. It was also shown that different ownership structures had different influences on governance and responsiveness during a time of crisis.
ORIGINAL SCIENTIFIC PAPER

RECEIVED: NOVEMBER 2019

REVISED: OKTOBER 2020

ACCEPTED: DECEMBER 2020

DOI: $10.2478 /$ ngoe-2020-0020

UDK: 005.7:336.71:336.5$(4-191.2)(4-11)$

JEL: G21, G30, G32, G34, K49

Citation: Festić, M., Črepinko, P., Bratina, B. (2020). The Importance of Corporate Governance of Banks Concerning the Ownership in the International Environment. Naše gospodarstvo/Our Economy, 66(4), 11-27. DOI: 10.2478/ ngoe-2020-0020

\section{NG OE}

NAŠE GOSPODARSTVO OUR ECONOMY

\begin{tabular}{l|l|l} 
Vol. 66 & No. 4 & 2020 \\
\hline
\end{tabular}

pp. $11-27$ 
This research addresses whether state ownership had a negative influence on corporate governance and, subsequently, on bank performance.

Central European countries in transition privatized most state-owned companies. Different methods were used for privatization that reflected on different types of ownership structures. Ownership concentration refers to the number of shares owned by individual shareholders and institutional investors.

The results of different research show that the structure of bank ownership has a strong influence on bank performance. Much research has been carried out in the last decades on corporate governance, but researchers have not been unanimous about its influence on performance, how important factors differed among countries, or what the most efficient measures and conditions for the improvement of corporate governance and, potentially, its influence on performance are.

We analyzed the correlation between ownership concentration and corporate governance. Based on our research results it can be confirmed that bank ownership structure has an impact on corporate governance. This means that bank ownership structure has effects on the relationship between corporate governance and bank performance. We structured the corporate governance index, which consists of an indicator of commitment to CG, an indicator of monitoring and auditing, an indicator of the supervisory board and management structure, an indicator of stakeholder care, and an indicator of transparency and disclosure. The analysis was done on the case of Eastern European Countries and it is the contribution of our research.

\section{Literature Overview: Corporate Governance}

Organization for Economic Cooperation and Development (hereinafter OECD) in its Principles of Corporate Governance (2009) defined corporate governance as one of the key elements for the improvement of economic efficiency and growth, as well as for increasing investor confidence. According to the OECD definition, corporative governance is comprised of a set of relationships among the company management, its board, its shareholders, and other stakeholders. Corporate governance also provides the structure through which the objectives of the company are set and the tools for attaining those objectives and monitoring performance. An effective system of corporate governance and the national economy contribute toward building an environment of trust necessary for the proper functioning of a market economy.
Corporate governance is a part of a wider economic context, comprised of macroeconomic policies and market factors, namely the legal, regulatory, and institutional environment. Additionally, it incorporates business ethics and the responsibility of companies to the environmental and social development of society.

Company power should be distributed according to the risk level attributed to individual stakeholders. The role of management is to adjust the interests of individual stakeholders. The supervisory board should, in addition to assessing financial statements, set up assessment mechanisms for evaluating management work and strategy implementation, as well as improving their expertise for successful functioning in boards (e.g. the audit board, risk management, remuneration, etc.).

Worldwide, different systems of corporate governance are used. The Anglo-Saxon model emphasizes the interests of shareholders, whereas the models used in Europe and Japan consider the interests of all stakeholders - shareholders, employees, managers, suppliers, buyers, and the community.

Jensen (1993) reported that there were four categories of mechanisms in corporate governance, aimed towards solving problems that stem from the divergence between management decisions and optimal decisions for the company, namely: (1) capital markets, i.e. mechanisms of external control; (2) legal/political/regulatory arrangements, i.e. legal and legislative mechanisms; (3) product markets, i.e. product market competition, and (4) internal control led by the supervisory board, i.e. internal control mechanisms. Shleifer and Vishny (1997) argued that the mechanisms of corporate governance were economic and legal institutions that can be altered during a political process to ensure a return on invested capital for the investors. When analyzing the mechanisms of governance, they focused mainly on incentive contracts, legal protection, and power for investors, above all with regard to the arbitrary actions of the management (protection of minority shareholder rights) and the ownership of large investors (concentrated ownership), i.e. matching of important control rights with important cash flow rights. Denis (2001) wrote about four governance mechanisms: (1) legal and regulatory mechanism, which are external to the company, (2) internal governance mechanisms, which include boards of directors, remuneration, ownership, and debt; (3) external governance mechanisms, i.e. the takeover market, and (4) product market competition. Hughes and Mester (2010) asserted that internal discipline can be established through the organizational form, ownership structure, capital structure, management boards, and the remuneration of management. External discipline is influenced by government 
regulation and a secure network as well as through the capital market discipline (takeovers, cost of assets, the ability of stakeholders to sell shares, competition on the manager job market, external blockholders, and the competition on the product market).

\section{The Influence of ownership structure on corporate governance}

Central European countries in transition privatized most state-owned companies. Different methods have been used for privatization, which was reflected in different structures of ownership. Ownership concentration refers to the number of shares owned by individual shareholders and institutional investors. Large shareholders tend to seek a high level of control over company management. The same interest is shown by institutional investors (e.g. mutual funds, pension funds), which operate with large quantities of money and want to ensure appropriate yield. Large shareholders have a lively interest in monitoring the performance of the supervisory board and management.

Initially, the research was focused on the idea that companies were owned by shareholders, that ownership was diversified, and that supervisors were not shareholders. During the late '80s, research showed that many companies were owned by large shareholders (Denis \& McConnell, 2003). Erkens et al. (2012) discovered that companies with larger institutional ownership operated less successfully during the 2007 crisis, noting that institutional owners had taken greater risks before the crisis. They also discovered that such companies had lower yields per share during the crisis, mainly because before the crisis independent managers and institutional shareholders encouraged managers to increase shareholder yields by making risky decisions.

On the other hand, Aljifri and Moustafa (2007) asserted that institutional investors did not have an important influence on company operations, whereas state ownership did. As noted by Denis and McConnell (2003), supervisors often own a part of the company they supervise. It is reasonable to conclude that a higher overlap between ownership and supervision leads to a lower conflict of interests and, consequently, towards a higher value of the company. If owners are managers, this contributes towards the harmonization of interests between management and company owners. Higher management ownership and the fact that the interests of owners and the management are not consistent can ensure more freedom for the management and enables them to follow their interests. When the ownership is diversified and when parts of the company are owned by small shareholders, there is little incentive for spending a lot of resources on management monitoring or for influencing the decision making within the company.
For many small shareholders »free-rider problem « reduces incentives for coordinating their activities. Denis and McConnell (2003) discovered that when blockholders (large shareholders) used their power, it is more likely that decisions will be made that increase the value for all shareholders. Nevertheless, blockholders also have some personal benefits. These benefits may not be harmful to other shareholders, e.g. access to influential people for large shareholders. The effect of ownership of benefits of supervision over large owners and the potential private value exploration of the company by large owners.

Many studies discussed the question of whether the effects of privatization were reflected in the operating performance of companies. Megginson, Nash, and Van Randenborgh (1994) investigated 61 state-owned firms from 18 countries, which had been privatized between 1979 and 1990. The results showed that, on average, privatized companies increased their sales, became more profitable, improved their operating efficiency, and increased the number of employees. Similar findings were reported by Boubakri and Cosset (1998), who studied 79 firms from 21 developing countries between 1980 and 1992. Claessens and Djankov (1999) also reported higher productivity and growth on a sample of 6354 privatized firms from Eastern European countries during the period 1992-1995. On the other hand, Dewenter and Malatesta (2001) found that government-owned firms were considerably less profitable and efficient than privately-owned companies but did prove that privatization alone did not influence higher profitability. On the other hand, they identified that profits increase within the three years before privatization.

Majumdar (1998) found that privately-owned enterprises were more efficient than state-owned or mixed-ownership enterprises. He also stated that mixed-ownership firms operated more efficiently than state-owned companies. Frydman, Gray, Hessel, and Rapaczynski (1999) argued that the influence of privatization was not the same for different types of companies and that efficiency did not improve when »insiders « were present in ownership structure, but only when external owners were present (i.e. non-employees). In a sample of Czech firms, Claessens and Djankov (1999) discovered that the more ownership structure is concentrated, the higher the company profitability and labor productivity.

\section{The influence of remuneration}

Remuneration is a mechanism of governance, which is based on performance. Individuals are offered bonuses, company shares, higher performance rewards, additional days off work, and other perks (see Słomka-Gołębiowska 
\& Urbanek, 2014). By remunerating good work, the company improves its business operations. The selection of appropriate remuneration (salary, bonuses, long-term incentives) is important because it aligns management's interests with the interests of shareholders.

\section{The influence of transparency}

Firms can reveal pay packages voluntarily when there is no system of compulsory disclosure. Millar et al. (2005) found out that the ideal system of corporate governance in the $21^{\text {st }}$ century does not exist, but that the most efficient systems should follow an integral approach, which encompasses aspects of different systems that are used around the world. Research findings of Millar, \& Eldomiaty et al. (2005) also showed the influence of business systems on corporate governance practices, with transparency being one of the determinants of efficiency in the model of corporate governance. Institutional transparency is closely related to information revealed to company shareholders but depends on the ownership structure. The disclosure of information, i.e. transparency, depends on institutional regulation for different types of business systems, among which the efficiency of legal institutions is of the utmost importance because it sets the borders between obligatory and voluntary information disclosure. The fierce competition requires that firms respond quickly and do not wait for the new legislation in the field of disclosures, which will tell them what, where, why, how, and when to make disclosures to their shareholders.

Mahoney and Mei (2009) stated that there is no proof that new disclosure requirements, which, for instance, are set in securities legislation and refer to the remuneration of management and large shareholders, reduced the asymmetry of information. Firms that disclose information regarding their operations reveal their business operations to the competition, but on the other hand, take care of their development and progress. This is, in times of fierce competition, of extreme importance.

\section{Principles for the improvement of corporate governance}

A healthy banking system is a precondition for a sound corporate operation and a strong stock market. According to Ribnikar (2009), therefore the state must introduce »suitable normative rules that regulate the functioning of credit institutions «. During the crisis, banks increased their dependence on the state, which ensured them liquidity and survival. Undoubtfully, the last financial crisis also shows that management and supervisory boards did not fulfill their role.
Due to all shortcomings in corporate governance, even more so during the times of crisis that started in the middle of 2007, the Basel Committee on Banking Supervision decided to revise the guidelines.

Sound corporate governance requires efficient legislation and regulation. Several factors including business law, stock exchange rules, and accounting standards can also influence market integrity and system stability but are frequently outside the scope of bank supervision.

Improvement of corporate governance was based on 14 principles (Basel Committee on Banking Supervision, 2010).

1. The board should carry out responsibility for the bank. It approves and oversees the implementation of the bank's strategic goals, risk strategy, corporate governance, and corporate values.

2. Board members should be and remain qualified, including through training. They should have a clear understanding of their role in corporate governance and be able to exercise sound decisions about the affairs of the bank.

3. The board should define appropriate governance practices for its work and ensure that such practices are followed and upgraded.

4. The group board is responsible for adequate corporate governance across the group and ensure there are governance policies and mechanisms appropriate to the structure, business, and risks of the group and its entities.

5. Under the direction of the board, senior management should ensure that the bank's activities are consistent with the business strategy, risk tolerance, and policies approved by the board.

6. Banks should have an effective internal control system and a risk management function (including a chief risk officer) with sufficient authority, stature, independence, resources, and access to the board.

7. Risks should be identified and monitored on an ongoing firm-wide and individual entity basis. Bank's risk management and internal control should keep pace with any changes to the bank's risk profile (including its growth) and the external risk landscape.

8. Effective risk management requires robust internal communication about risks, both across the organization and through reporting to the board and senior management.

9. The board and senior management should effectively utilize the work conducted by internal audit functions, external auditors, and internal control functions.

10. The board should actively monitor and review the compensation system (design and operation) to ensure that it operates as intended. 
11. Employee compensation should be aligned with prudent risk-taking adopted by the bank. It should be adjusted to all types of risks and symmetric with risk outcomes. Compensation payouts schedules should be sensitive to the time horizon of risks. Compensation payout (mix of cash, equity, and other forms of compensation) should be consistent with risk alignment and will likely vary across employees, depending on their position a role in the bank.

12. The board and senior management should know and understand the bank's operational structure and the risks that it poses.

13. When a bank operates through special-purpose or in environments that impede transparency or do not meet international banking standards, its board and senior management should understand the purpose, structure, and risks of these operations and see to mitigate the identified risks.

14. The governance of the bank should be transparent to its shareholders, depositors, other relevant stakeholders, and market participants.

Weaknesses of corporate governance in financial institutions are primarily related to legal protection, rule of law, conflicts of interest, and other factors.

Himmelberg, Hubbard, and Love (2002) noted that the lack of legal protection for investors is reflected in the larger ownership share of the company's capital owned by internal shareholders (i.e. there is a negative link).

Dittmar, Mahrt-Smith, and Servaes (2003) claimed that companies in countries in which shareholder rights are not well-protected and have surplus cash (i.e. companies have up to twice as much money as companies in countries with good legal protection of shareholders).

Research showed that better legal protection for investors is linked to the higher valuation of stock markets (La Porta, Lopez-de-Silanes, \& Shleifer, 2002). Industry and companies in better legal regimes rely more on external sources of funding for their growth (La Porta, Lopez-de-Silanes, Shleifer, \& Vishny, 1997). Greater security for investors also increases the desire for investors to finance and is reflected in lower costs and greater access to external funding sources (Durnev, \& Kim, 2005).

La Porta, Lopez-de-Silanes, Schleifer, and Vishny (1998) claimed that the legal system was a fundamentally important mechanism of corporate governance. The degree to which national law protects the rights of investors and to which laws are implemented is the most basic determinant of the direction under which corporate finance and corporate governance in the country are implemented.
Gillan and others (2007) have shown that independent supervisory councils can serve as a substitute for the supervision of companies by the market and that causality takes place from the supervisory board to the choice of the provisions.

\section{Conflicts of interest}

Due to the systemic risks, the diversity of transactions, the diversity of financial services, and the complex structure of large financial groups, conflicts of interest in financial institutions have an even greater significance (Burkart, \& Panunzi, 2001). Conflicts can arise in a variety of situations such as when exercising incompatible roles or activities, or between a financial institution and its shareholders/investors where there is cross-shareholding or a business link between an institutional investor and a financial institution in which it is investing.

\section{The role of shareholders}

New categories of shareholders have appeared, which seem to show little interest in the long-term governance objectives of the businesses or financial institutions in which they invest. They focus, instead, primarily on short-term (quarterly or half-yearly) goals, which encourages excessive risk-taking. Often, a director's interests followed these short-term interests that amplified risk-taking and contributed to excessive remuneration for directors, based on the short-term share value of shares as the only performance criterion. The disinterest of shareholders concerning their financial institutions can be explained by several factors, described below (Francis et al., 2013):

- Certain profitability models, based on possession of portfolios of different shares, lead to the disappearance of the concept of ownership normally associated with holding shares;

- If the participation of shareholders is minimal, the cost that institutional investors would face if they wanted to actively engage in governance can dissuade them;

- Conflicts of interest;

- The lack of effective rights to exercise control; obstacles related to the lack of cross-border voting rights; uncertainty regarding legal concepts; and financial institutions' disclosure of information being too complicated.

When politicians serve as proprietary directors, representing large shareholders, or as executive directors, there is some evidence that board monitoring performance deteriorates (Pascual-Fuster and Crespí-Cladera, 2018).

\section{The role of supervisory authorities}

Supervisory authorities possess tools enabling them to intervene in the internal governance of financial institutions, 
but due to financial innovations and the rapid change in the business model of these institutions, effective supervision has not been always carried out. Besides, the supervisory authorities often have failed to enforce strict eligibility criteria for members of boards of directors nor do they check if their risk management systems and internal organization were adapted to changes in their business model and financial innovations.

\section{The role of auditors}

Auditors have played a key role in the financial systems of corporate governance systems because the auditors assured that the financial statements prepared are credible. However, conflicts of interest can arise, because audit firms were remunerated by the very same companies who mandate them to audit their financial accounts. Financial reporting quality was higher for firms whose board's audit committees had a greater proportion of independent directors who reside close to a firm's headquarters than for firms whose boards consist of directors who are more geographically dispersed (Firoozi et al., 2018).

Also, the importance of ownership structure for corporate governance of banks is described below:

\section{Board of directors}

At the heart of the origins of the 2007 crisis was the failure of financial institutions to identify, understand, and control risks for many of the following reasons:

- Members of boards of directors (in particular non-executive directors) devoted neither sufficient resources nor the time to the fulfillment of their duties;

- Members of boards of directors did not come from sufficiently diverse backgrounds in terms of gender, social, cultural, and educational backgrounds;

- Boards of directors (in particular their chairmen) did not carry out a serious performance appraisal of their members or the board of directors as a whole;

- Boards of directors were unable to ensure the appropriate risk management framework;

- Boards of directors were unable to recognize the systemic nature of some risks, and thus, did not provide sufficient information to their supervisory authorities.

There is also a question about the quality of appointment procedures for members of the boards of directors (Becht et al., 2002).

Problems related to the efficient implementation of corporate governance in financial institutions

The 2007 crisis showed that the principles of corporate governance were not efficient in the financial services sector, especially in banks. Weaknesses defined in the Green Paper were the following (European Commission 2010a, 2010b):

- The existing principles of corporate governance were too broad in scope and were not sufficiently precise, giving financial institutions too much scope for interpretation;

- Within the financial institution and the supervisory authority, roles and responsibilities for implementing the principles were not allocated;

- The principles were based on non-binding recommendations by international organizations or the provisions of corporate governance with a lack of relevant checks and an absence of deterrent penalties.

\section{Risk management}

Risk management is one of the key aspects of corporate governance in financial institutions, which was not managed holistically. The main shortcomings were (Tandelilin et al. 2007):

- A lack of understanding of the risks on the part of those involved;

- A lack of authority on the part of the risk management function to have sufficient powers and authority to be able to curb the activities of risk-takers;

- Lack of expertise in risk management. The assessment of expertise was focused only on priority risks and did not cover any other risks;

- A lack of real-time information on risks. It is important to set up an efficient flow of clear and correct information on risks and to upgrade IT tools for risk management so that risks can be consolidated rapidly, allowing the evolution of group exposures to be followed up effectively in real-time.

Particular responsibility for the implementation of good practices of risk management on all levels lies with the directors of financial institutions because directors must be themselves exemplary.

\section{Ownership structure}

Schleifer and Vishny (1997) discussed the importance of legal protection and concentrated ownership for sound corporate governance. Improved control over the largest shareholders leads to actions that increase company value and the overall position of all shareholders. On the other hand, concentrated ownership makes it possible for the largest shareholders to have discretionary power to achieve their advantages on behalf of other shareholders, which may lead to a decrease in the company value.

Magalhaes et al. (2010) claimed that a concentrated ownership structure enables more efficient control, and, consequently, improves business operations. In the same manner, Caprio et al. (Caprio, Laeven, \& Levine, 2007) 
concluded that concentrated ownership represents an important mechanism for governing banks. They found that greater rights of controlling shareholders over the cash flow increase bank value. That larger concentration of ownership increases bank value was also confirmed by Li and Song (2010), while Love and Rachinsky (2007) believe that banks with highly concentrated ownership have considerably poorer corporate governance.

The influence of ownership (foreign/domestic) and corporate governance (the composition of the board - external and/or foreign members) on performance (profit) and bank risks was studied by Choi and Hasan (2005). The results of their research show that there is a positive and significant correlation between foreign ownership and the operation of banks. Foreign ownership per se does not have an important influence, but the scope of foreign ownership has a positive and statistically significant influence on bank profit and risk. Banks employing a combination of increased foreign ownership and the presence of a foreign director on the board were associated with positive and significant bank performance. The influence of increased foreign ownership on bank's interest revenues was studied by Lensink and Naaborg (2007). The results of their research show that an increase of foreign ownership has a negative and strong influence on the operation of banks, above all in terms of net interest revenues and profitability. ${ }^{1}$ Banks with a lower degree of foreign ownership are more profitable and able to raise more net interest revenues. Tandelilin et al. (2007) found out that bank ownership influences both-the relationship between corporate governance and bank operations and the relationship between corporate governance and risk management. Banks with foreign owners have a better implemented corporate governance than banks owned by the state or domestic banks that are privately owned. The authors proved the hypothesis that better corporate governance leads to improved bank performance.

Barako and Tower (2007) studied the relationship between ownership structure and bank performance. The results of their research showed that a bank's ownership structure had a strong influence on bank performance. The ownership of the board and the ownership by the state are significantly and negatively correlated with bank performance.

\footnotetext{
${ }^{1}$ In the banks struggling with profitability the balance sheet was shrinked by reducing their lending to meet stricter capital requirements at the early stage of Basel III (more in Andrle et. al. 2019). There are significant differences in lending behavior between domestic and foreign banks (see, Fidrmuc \& Kapounek 2019). Foreign owners have significant participation in domestic banks (when there are constraints on the supply of credit and as the external solvency of the economy and the banking sector is ensured by their negative international investment position). Banks face increasing regulatory requirements under Basel III (see Brůna \& Blahová 2019).
}

Institutional shareholders did not significantly correlate with performance, but foreign ownership had a significant and positive correlation with bank performance. Cornett et al. (2010) found that, in the period between 1989 and 2004, state-owned banks performed with lower profits, they had core capital, and were a greater credit risk than privately-owned banks. The difference in bank performance was particularly strong in countries with greater government involvement and political corruption in the banking system. The difference between state-owned banks and privately-owned banks was lessened after the crisis in the period from 2001 to 2004. Wen (2010) found out that there was no apparent correlation between ownership structure and bank operations. He stated that state-owned commercial banks can reach a square ratio with ROE (return on equity).

Spong and Sullivan (2007) found that manager ownership can improve bank performance. Boards have a positive influence on bank performance when directors had an important financial interest in the bank. The wealth and financial position of managers and directors were negatively correlated, and manager ownership was positively correlated, which was an important correlation with risk-taking.

\section{Research: Empirical Analysis of Corporate Governance and Its Influence on Bank Operations in Selected Countries}

Much research has been done dealing with corporate governance. However, researchers have often studied only the influence of a certain spectrum of governance. Also, research has often failed to give an extended insight into corporate governance and its influence on performance. This research mainly deals with the impact of ownership structure (Love \& Rachinsky, 2007; Lskavyan \& Spatareanu, 2006; Magalhaes et al., 2010; Li \& Song, 2010; Choi \& Hasan, 2005; Lensink \& Naaborg, 2007) or the impact of the structure of management boards (Adams \& Mehrana, 2003; Kyereboah-Coleman \& Biekpe, 2006; Dahya et al., 2008; Li \& Song, 2010; Choudhry, 2011) on corporate governance. In addition, research on remuneration, social responsibility, and corporate governance can be found in the literature.

Despite the vast amount of research carried out during the last decades, researchers have not been unanimous about the influence of corporate governance on performance, nor about how important factors differ among countries, or what are the most efficient measures and conditions for the improvement of corporate governance and its influence on actual performance. 
Corporate governance variables were divided into five sets of indicators that form the so-called corporate governance index. Figure 1 shows a schematic presentation of the model of corporate governance. Performance of corporate governance was measured with indicators: return on average assets (ROAA), return on average equity (ROAE), and net interest income (NETII). ${ }^{2}$

\section{Research variables}

Table 1 shows a list of all independent variables. Based on selected parameters (variables) we designed a matrix and then, based on a review of annual reports, collected the required data.
Five indicators were used in our research, namely:

- Indicator of commitment to CG,

- Indicator of monitoring and auditing,

- Indicator of the supervisory board and management structure,

- Indicator of stakeholder care,

- Indicator of transparency and disclosure.

Individual variables for an indicator are dummy variables, with the value 1 representing sound governance, whereas the value 0 represents poor governance. The sum of the values of variables form indicators or the so-called index of corporate governance. Subsequently, the index values were standardized.

Figure 1. The model of corporate governance and its impact on bank performance ${ }^{3}$

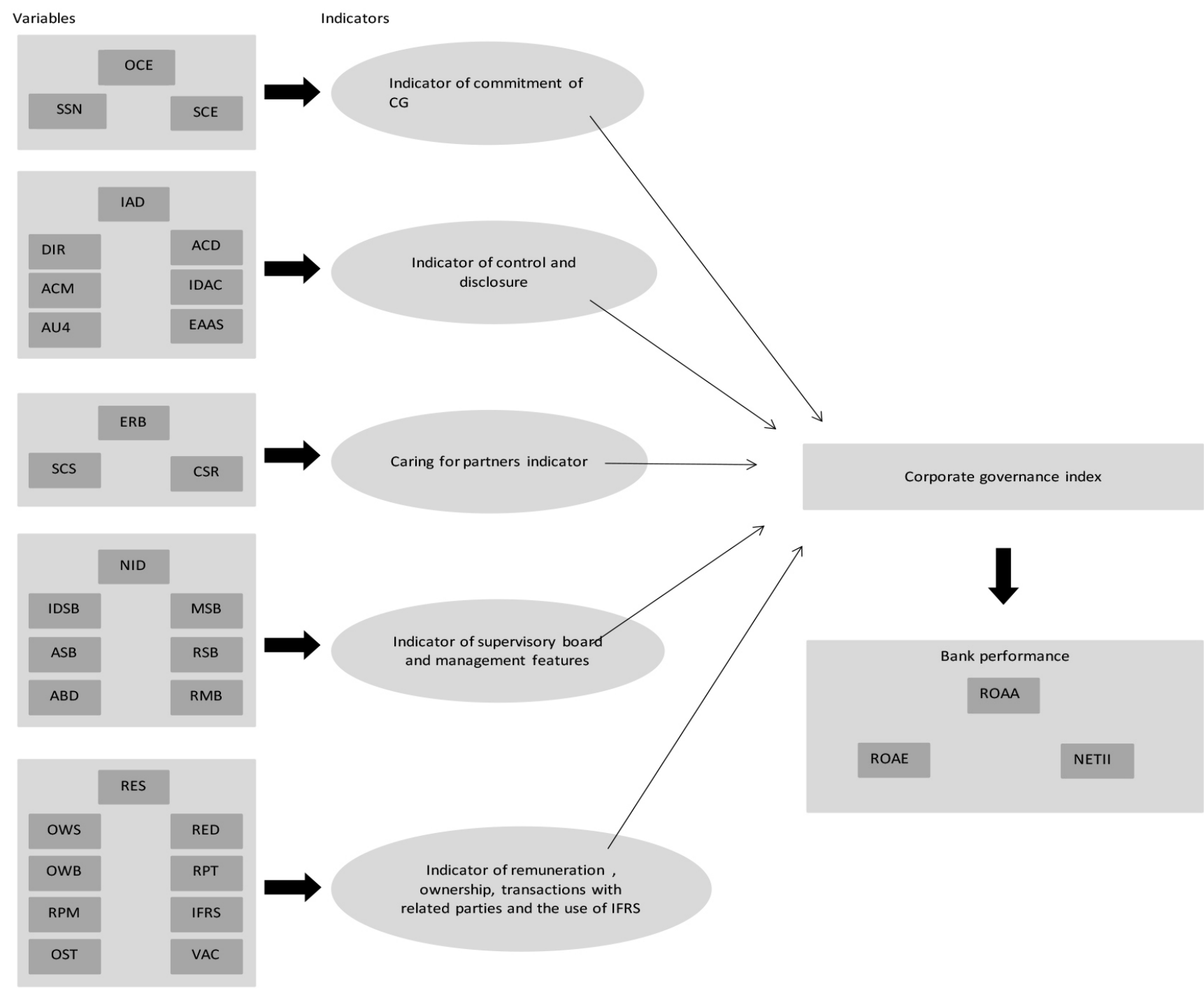

2,3 The abbreviations are explained in Table 1. 
Table 1. List of independent variables

\begin{tabular}{|c|c|c|c|}
\hline Independent variable & Symbol & Description & Source \\
\hline $\begin{array}{l}\text { Indicator of commitment to } \\
\text { CG (corporate governance) }\end{array}$ & CG & $\begin{array}{l}\text { Indicator of commitment CG comprises three variables 1) Own code CG, 2) Chapter on CG, 3) } \\
\text { Declaration of compliance with the code. }\end{array}$ & Own calculations \\
\hline Own code on CG & OCE & 1 if the bank has its own code CG; 0 if the bank does not have its own code. & $\begin{array}{l}\text { Annual reports and } \\
\text { own calculations }\end{array}$ \\
\hline Chapter on CG & SSN & $\begin{array}{l}1 \text { if bank annual report includes a chapter on CG; } 0.5 \text { if the annual report includes only some data } \\
\text { related to CG; } 0 \text { data regarding CG are not disclosed }\end{array}$ & $\begin{array}{l}\text { Annual reports and } \\
\text { own calculations }\end{array}$ \\
\hline $\begin{array}{l}\text { Declaration of compliance } \\
\text { with the code }\end{array}$ & SCE & $\begin{array}{l}1 \text { if the bank's annual report includes declaration of compliance with the code CG; } 0 \text { if the declaration } \\
\text { of compliance does not exist. }\end{array}$ & $\begin{array}{l}\text { Annual reports and } \\
\text { own calculations }\end{array}$ \\
\hline $\begin{array}{l}\text { Indicator of control } \\
\text { and audit }\end{array}$ & & $\begin{array}{l}\text { Indicator of control and audit comprises } 7 \text { variables: } 1 \text { ) the existence of internal auditing department, 2) } \\
\text { if internal audit reports directly to the board, 3) the existence of auditing board (AB), 4) disclosure of names } \\
\text { and functions of members of auditing board, 5) (in)dependency of the president of } A B, 6 \text { ) if the external auditor } \\
\text { is one of the four international auditing companies and 7) additional services of internal auditor. }\end{array}$ & Own calculations \\
\hline Internal auditing department & IAD & 1, if the annual report discloses that the firm has internal auditing department; 0 , if this is not the case. & $\begin{array}{l}\text { Annual reports and } \\
\text { own calculations }\end{array}$ \\
\hline $\begin{array}{l}\text { Direct reporting } \\
\text { of internal audit }\end{array}$ & DIR & 1 , if internal auditors report directly to the board; 0 , if this is not the case. & $\begin{array}{l}\text { Annual reports and } \\
\text { own calculations }\end{array}$ \\
\hline Audit board (AB) & ACD & 1 , if the firm has an $A B ; 0$, if this is not the case. & $\begin{array}{l}\text { Annual reports and } \\
\text { own calculations }\end{array}$ \\
\hline Disclosure of members & ACM & $\begin{array}{l}1 \text {, if the name and function of } A B \text { is disclosed outside the audited company; } 0.5 \text {, } \\
\text { if only the name of the member is disclosed; } 0 \text {, if members of } A B \text { are not disclosed. }\end{array}$ & $\begin{array}{l}\text { Annual reports and } \\
\text { own calculations }\end{array}$ \\
\hline Independent president & IDAC & 1 , if the president of $A B$ is independent; 0 , if this is not the case. & $\begin{array}{l}\text { Annual reports and } \\
\text { own calculations }\end{array}$ \\
\hline External auditor - "big 4" & $\mathrm{AU} 4$ & 1, if external auditor is one of the four international auditing companies; 0 , if this is not the case. & $\begin{array}{l}\text { Annual reports and } \\
\text { own calculations }\end{array}$ \\
\hline $\begin{array}{l}\text { Additional services } \\
\text { of external auditor }\end{array}$ & EAAS & $\begin{array}{l}\text { 1, if external auditor does not offer any other services to the bank (consultancy, etc.); } \\
0 \text {, if external auditor does offer additional services to the bank. }\end{array}$ & $\begin{array}{l}\text { Annual reports and } \\
\text { own calculations }\end{array}$ \\
\hline Indicator of caring for partners & & $\begin{array}{l}\text { Indicator of caring for partners comprises of three variables: } 1 \text { ) the presence of employee representative in supervi- } \\
\text { sory board (SB), 2) support of activities in the area of social responsibility and 3) reporting on social responsibility. }\end{array}$ & Own calculations \\
\hline $\begin{array}{l}\text { Employee representative } \\
\text { in supervisory board }\end{array}$ & ERB & 1, if employees have their representative in SB; 0 , if this is not the case. & $\begin{array}{l}\text { Annual reports and } \\
\text { own calculations }\end{array}$ \\
\hline $\begin{array}{l}\text { The firm supports activities } \\
\text { in the area of social respon- } \\
\text { sibility }\end{array}$ & SCS & $\begin{array}{l}\text { 1, if the bank discloses activities in the area of responsibility towards employees, environment, donation, etc.; } \\
0 \text {, if this is not the case. }\end{array}$ & $\begin{array}{l}\text { Annual reports and } \\
\text { own calculations }\end{array}$ \\
\hline Report on social responsibility & CSR & $\begin{array}{l}\text { 1, if, in addition to the annual report, the bank has a separate report on social responsibility; } \\
0.5 \text {, if annual report consists of a chapter on social responsibility; } 0 \text {, if this is not the case. }\end{array}$ & $\begin{array}{l}\text { Annual reports and } \\
\text { own calculations }\end{array}$ \\
\hline $\begin{array}{l}\text { Indicator of supervisory board } \\
\text { and management features }\end{array}$ & & $\begin{array}{l}\text { Indicator of supervisory board (SB) and management features consists of seven variables: } \\
\text { 1) independence of board members, 2) independence of board president 3) membership/employment } \\
\text { of members SB, 4) assessment policy for members of the SB, 5) remuneration of members of the SB, } \\
\text { 6) assessment system for the members of SB,7) management remuneration. }\end{array}$ & Own calculations \\
\hline $\begin{array}{l}\text { Independence of supervisory } \\
\text { board members }\end{array}$ & NID & 1 , if the SB comprises of independent members; 0 , if this is not the case & $\begin{array}{l}\text { Annual reports and } \\
\text { own calculations }\end{array}$ \\
\hline $\begin{array}{l}\text { The president of } \\
\text { SB is independent }\end{array}$ & IDSB & 1, if the president of SB is independent; 0 , if this is not the case. & $\begin{array}{l}\text { Annual reports and } \\
\text { own calculations }\end{array}$ \\
\hline $\begin{array}{l}\text { Membership/employment } \\
\text { of members of SB }\end{array}$ & MSB & 0 , if members of the SB are members of other SBs or if data are not disclosed; 1 , if this is not the case. & $\begin{array}{l}\text { Annual reports and } \\
\text { own calculations }\end{array}$ \\
\hline $\begin{array}{l}\text { Assessment policy/procedure } \\
\text { for members of supervisory } \\
\text { board }\end{array}$ & ASB & 1 , if the assessment system for members of SB is disclosed; 0 , if this is not the case. & $\begin{array}{l}\text { Annual reports and } \\
\text { own calculations }\end{array}$ \\
\hline Remuneration of SB & RSB & $\begin{array}{l}\text { 1, if remuneration for individual members of } S B \text { is disclosed } 0.5 \text {, if the aggregate remuneration } \\
\text { of members of } S B \text { is disclosed; } 0 \text {, if remuneration is not disclosed. }\end{array}$ & $\begin{array}{l}\text { Annual reports and } \\
\text { own calculations }\end{array}$ \\
\hline $\begin{array}{l}\text { Assessment policy system for } \\
\text { the board }\end{array}$ & $A B D$ & 1 , if assessment policy system is disclosed; 0 , if this is not the case. & $\begin{array}{l}\text { Annual reports and } \\
\text { own calculations }\end{array}$ \\
\hline Remuneration & RMB & $\begin{array}{l}\text { 1, if remuneration is disclosed by individual members; } 0.5 \text {, if aggregate remuneration is disclosed; } \\
0 \text {, if remuneration is not disclosed. }\end{array}$ & $\begin{array}{l}\text { Annual reports and } \\
\text { own calculations }\end{array}$ \\
\hline $\begin{array}{l}\text { Indicators of remuneration, } \\
\text { ownership, transactions with } \\
\text { related persons and the use } \\
\text { of IFRS }\end{array}$ & & $\begin{array}{l}\text { Indicators of remuneration, ownership, transactions with related parties and the use of IFRS comprise of } 11 \\
\text { variables: 1) remuneration SB, 2) ownership of SB, 3) remuneration of management, 4) ownership of manage- } \\
\text { ment, 5) transactions with related parties ,6) transactions with related parties according to individual members } \\
\text { of SB and management 7) use of IFRS, 8) disclosure of ownership structure and 9) variable remuneration. }\end{array}$ & Own calculation \\
\hline $\begin{array}{l}\text { Remuneration - supervisory } \\
\text { board }\end{array}$ & RES & $\begin{array}{l}\text { 1, if remuneration is disclosed for each individual member; } 0.5 \text {, if data are disclosed on the aggregate level } \\
\text { for the SB; } 0.25 \text {, if data are disclosed for the SB and management; } 0 \text {, if data are not disclosed. }\end{array}$ & $\begin{array}{l}\text { Annual reports and } \\
\text { own calculations }\end{array}$ \\
\hline Ownership - supervisory board & OWS & $\begin{array}{l}\text { 1, if ownership of individual SB is disclosed; } 0.5 \text {, if ownership is disclosed on the aggregate level; } \\
0 \text {, if ownership is not disclosed. }\end{array}$ & $\begin{array}{l}\text { Annual reports and } \\
\text { own calculations }\end{array}$ \\
\hline Remuneration - board & RED & $\begin{array}{l}\text { 1, if remuneration of individual board members is disclosed; } 0.5 \text {, if data is disclosed on the aggregate level for the } \\
\text { whole management; } 0.25 \text {, if data are disclosed together for the SB and management; } 0 \text {, if data are not disclosed. }\end{array}$ & $\begin{array}{l}\text { Annual reports and } \\
\text { own calculations }\end{array}$ \\
\hline Ownership - board & OWB & $\begin{array}{l}\text { 1, if ownership of individual members of the board is disclosed; } 0.5 \text {, if ownership is disclosed on the aggregate } \\
\text { level; } 0 \text {, if ownership is not disclosed. }\end{array}$ & $\begin{array}{l}\text { Annual reports and } \\
\text { own calculations }\end{array}$ \\
\hline $\begin{array}{l}\text { Transactions with related } \\
\text { parties }\end{array}$ & RPT & $\begin{array}{l}\text { 1, if individual transactions are disclosed; } 0.5 \text {, if aggregate transactions are disclosed, } \\
\text { i.e. on the level of business transaction; } 0 \text {, if they are not disclosed. }\end{array}$ & $\begin{array}{l}\text { Annual reports and } \\
\text { own calculations }\end{array}$ \\
\hline $\begin{array}{l}\text { Transactions with related par- } \\
\text { ties - supervisory board and } \\
\text { management }\end{array}$ & RPM & $\begin{array}{l}\text { 1, if transactions for individual members of } \mathrm{SB} / \text { management are disclosed; } \\
0.5 \text {, if aggregate transactions are disclosed, i.e. for } \mathrm{SB} / \text { management together; } 0 \text {, if they are not disclosed. }\end{array}$ & $\begin{array}{l}\text { Annual reports and } \\
\text { own calculations }\end{array}$ \\
\hline $\begin{array}{l}\text { Use of IFRS (International Fi- } \\
\text { nancial Reporting Standards) }\end{array}$ & IFRS & 1 , if it is disclosed that the firm uses IFRS; 0 , if not disclosed. & $\begin{array}{l}\text { Annual reports and } \\
\text { own calculations }\end{array}$ \\
\hline Ownership structures & OST & $\begin{array}{l}\text { 1, if ownership structure is disclosed for at least } 5 \text { largest shareholders or for } 90 \% \text { of ownership; } \\
0.50 \text {, if ownership for a lower percentage is disclosed; } 0 \text {, if ownership is not disclosed. }\end{array}$ & $\begin{array}{l}\text { Annual reports and } \\
\text { own calculations }\end{array}$ \\
\hline Variable remuneration & VAC & $\begin{array}{l}\text { 1, if the amount of variable remuneration is disclosed separately from the total amount; } 0.5 \text {, if the amount of vari- } \\
\text { able remuneration is disclosed in the total amount of remuneration; } 0 \text {, if variable remuneration is not disclosed. }\end{array}$ & $\begin{array}{l}\text { Annual reports and } \\
\text { own calculations }\end{array}$ \\
\hline
\end{tabular}

${ }^{4}$ The abbreviations are explained in Table 1. 


\section{Sampling and its representativeness}

The ten largest banks represented the population of our research (according to the value of balance sheet assets) from eight countries in Central and Eastern Europe: the Czech Republic, Estonia, Latvia, Lithuania, Hungary, Poland, Slovakia, and Slovenia. We have chosen these countries due to the comparability of their historical and economic development. Besides, they are geographically close to each other. The chosen sample makes it possible to make comparisons of data with Slovenia, which is the center of our interest, as well as with other Central and Eastern European states.

Data were gathered for the period of 2005-2013. We decided on this period because it is an interesting period during which a serious financial and economic crisis occurred (in 2008) that was felt intensively in most studied countries. The chosen period also represents a period before and after the point in 2014. The implementation of additional directives regarding capital requirements also happened in a short period after 2013, which is why these years have been excluded from the research. This was appropriate because of the content and comparability of data, as the indicators of statistical significance for the gathered data improved. The inclusion of a longer period will become methodologically possible only with a longer period of implementation of the new regulatory requirements and by considering the inflection points of phases in the economic cycle. ${ }^{4}$ By considering different implementation timelines for additional capital requirements and an analysis of the crisis period, the comparability of data is better up to 2013.

\section{Methodological limitations}

When carrying out our empirical analysis, we encountered some methodological limitations. A methodological limitation was the choice of sample and its representativeness. The sample included a selection of countries from Central and Eastern Europe. Given the specificity of the countries studied, their geographical location, their historical and economic characteristics, the representativeness of results obtained can be questionable for the countries from non-comparable environments.

Inaccessibility of some data is another limitation. It appeared in the form of a lack of data. We tried to solve this issue of missing data in the Bankscope database by replacing the missing data with data available from public annual reports on bank web pages. If financial data or annual

\footnotetext{
${ }^{4}$ More on cycles and efficiency of banks, see Maripuu and Männasoo (2014) and Košak et al. (2009).
}

reports for a bank were unavailable for a certain year, the bank was excluded from the sample and the next biggest bank was placed on our list.

\section{Discussion: Results of Empirical Research}

We studied the influence of concentrated ownership, foreign ownership, and state ownership on the index of corporate governance.

The following variables were used to study the influence of concentrated ownership and ownership structure on corporate governance: the number of shareholders (NSH), the number of large owners (NLO), and the ownership of the five largest shareowners (\% O5S). These variables were used to find the correlation and influence of concentrated ownership of corporate governance.

At the same time, we studied the influence of foreign and state ownership on corporate governance. Two variables were used, namely the share of foreign ownership (\% FO) and the share of state ownership (\% SO).

The results of our research showed that in our sample of banks, the largest number of shareholders (NSH) was found in Slovakia, Slovenia, and the Czech Republic. This signaled a diversity of ownership in these countries. In countries like Estonia, Hungary, and Latvia, the number of shareholders was the lowest. In these countries, the concentration of ownership was the highest. At the same time, these countries had a large share of foreign ownership, greater than $50 \%$ in all of them.

The number of large owners (NLO), with the ownership share larger than 5\% was highest in Estonia (2.41) and Slovenia (2.27). In other countries, the average number of large owners was lower than 2. The largest maximal number of large owners was found in Estonia (11), Lithuania in Hungary (8), and Slovenia (7).

The average values of ownership share of shareholders that own more than $5 \%$ of shares (\% O5S), amounted to between $82 \%$ and $96 \%$. This suggests that the ownership concentration in all these countries if ownership share was larger than $5 \%$ was considered, was very high. No considerable differences have been found between the countries. The highest average value was found in the Czech Republic (96.18\%), the lowest in Poland (72.63\%).

The average value of ownership share of foreign shareholders among the 5 largest shareholders (\% FO) was highest in Slovakia (93\%) and lowest in Slovenia (51\%). 
It was found for the sampled countries that, in general, the percentage of state ownership among the 5 largest shareholders (\% SO) was low. The highest average percentage of state ownership among the 5 largest shareholders was found in Latvia (33.91\%), Poland (27.23\%), Slovenia (12.09\%), and the Czech Republic (8.82 \%). In most of these countries, a comparably lower ownership share of foreign shareholders among the 5 largest shareholders was observed. In line with our expectations, it was found that the share of state ownership is not necessarily inversely proportional to the share of foreign ownership. On the other hand, inverse proportionality was found in the case of domestic and foreign ownership.

When analyzing the results of descriptive statistics for the variables of ownership structure, the largest average number of shareholders was found in Slovakia, Slovenia, and the Czech Republic. On average, the highest number of large owners was found in Estonia and Slovenia. The ownership share of shareholders with more than $5 \%$ of shares is, on average, was very high, between $81 \%$ and $96 \%$. The share of foreign shareholders among the five largest shareholders was highest in Slovakia, Hungary, and Poland, but lowest in Slovenia. The percentage of state ownership among the five largest shareholders was highest in Latvia and Poland.

Table 2 shows the correlation between ownership structure and the corporate governance index, where we tested the correlation between the corporate governance index variable (index CG) and the number of all bank shareholders (NSH), the number of shareholders (from among the 10 largest) with more than 5\% of shares (NLO), ownership share of shareholders with more than 5\% shares (\% O5S), ownership share of foreign shareholders among the 5 biggest shareholders (\% FO), and the percentage of state ownership among the 5 biggest shareholders (\% SO). Correlation analysis was used for testing, in which the direction and strength of a linear relationship between two variables were measured.

The number of bank shareholders was statistically significant and positive with the corporate governance index in Latvia, Lithuania, Hungary, and Slovenia, with the most significant correlation in Hungary and Slovenia. The result is in line with expectations in which a lower ownership concentration has a positive influence on corporate governance. Slovakia had no statistically significant and negative correlations, which means that the number of owners was negatively correlated with the corporate governance index. This indicated that Hungary's lower ownership concentration correlates with poorer corporate governance.

When studying the correlation between the number of large shareholders and the corporate governance index, we found that in Lithuania the correlation between the number of large owners and corporate governance index was positive and statistically significant, at the level of 0.05. In Hungary, the magnitude of statistic relevance was higher, and the correlation was also positive and statistically significant at the level of 0.01. In Slovakia, the correlation was the same as the number of all shareholders, negative and statistically significant at the level of 0.01. In all the other countries (the Czech Republic, Estonia, Lithuania, Poland, Slovenia) the correlations were not statistically significant.

The results were slightly better in the calculation of the correlation of the ownership share of shareholders owning more than $5 \%$ of shares and the corporate governance index. The results were statistically significant in the case of Latvia, where the correlation was negative and statistically significant at the level of 0.05 . The same correlation was found between Lithuania and Slovenia. This result showed that in the case of interpreting the ownership share as the indicator of ownership concentration, it holds for the said countries that the higher ownership concentration correlated with poorer corporate governance. In other cases, the correlation was positive but not statistically significant. The result is consistent with our expectations, according to which lower ownership concentration positively correlated with corporate governance.

Considering the fact that when studying the correlation between the number of shareholders and corporate governance, that we found, in most cases, a positive and significant correlation and that the correlation between ownership share of shareholders with more than $5 \%$ of shares and corporate governance was most often negative, we concluded that a lower ownership concentration had a positive influence on corporate governance. Contrary to our expectations, the correlation between the number of large shareholders and corporate governance was most often positive, but rarely significant. A positive correlation was determined for only two countries (Latvia, Hungary). On the other hand, the correlation was negative and significant in Slovakia. The correlation between ownership share of shareholders with more than $5 \%$ shares and the corporate governance index was significant and negative in three countries (Latvia, Lithuania, Slovenia). In other countries, the correlation was not significant. By taking these findings into account, we concluded that the hypothesis that a smaller concentration of ownership (i.e. highly diversified ownership) had a positive influence on corporate governance.

For the sample of most countries (except Slovenia) it was determined that there is a positive correlation between the share of foreign capital among the five largest shareholders and the corporate governance index. The correlation was positive and significant on the level of 0.01 in the case of 


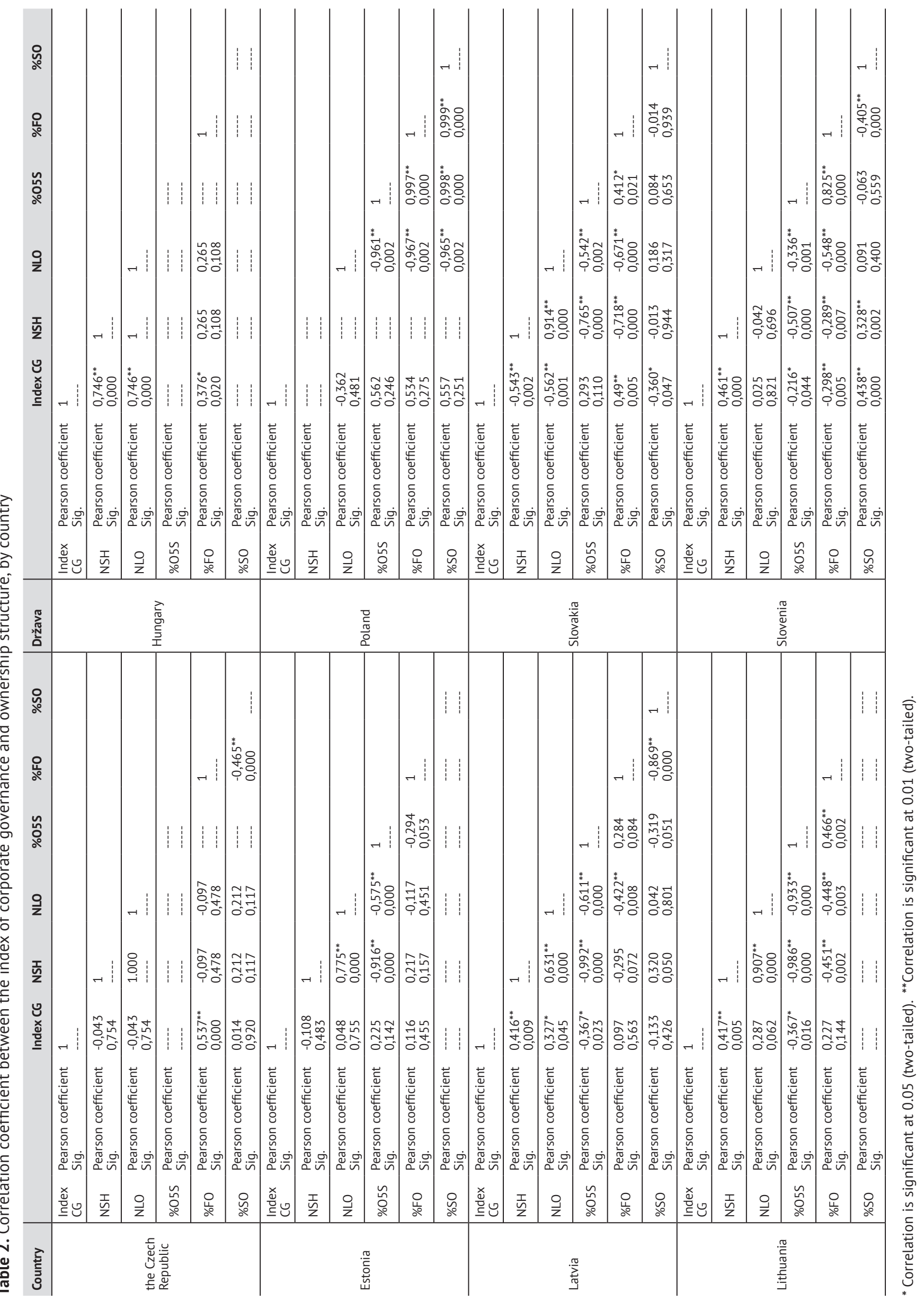


the Czech Republic and Slovakia. The correlation was positive and significant on the level of 0.05 in Hungary and negative and statistically significant on the level of 0.01 in Slovenia. Based on the results, it can be concluded that foreign ownership has a positive correlation with corporate governance. In most cases a positive and significant correlation was confirmed between the share of foreign ownership and corporate governance index, we can say that foreign ownership has a positive influence on corporate governance.

Data on state ownership among the five largest shareholders in Hungary, Lithuania, and Estonia were not disclosed. The results show that there is a statistically significant and negative correlation on the level of 0.05 between state ownership and corporate governance index in Slovakia, whereas for Slovenia the correlation was positive and significant on the level of 0.01 . For many countries, we could not prove that state ownership has a statistically significant and negative correlation with corporate governance, we cannot prove with sufficiently high certainty that state ownership has a bad influence on corporate governance, and consequently, bank performance.

According to the above findings, it can be confirmed that the ownership structure influences corporate governance. By studying partial hypotheses, we found out that less concentrated ownership and foreign ownership have a positive influence on corporate governance. However, we cannot say with certainty that state ownership has a negative effect on corporate governance.

\section{Key Findings: The Influence of Bank Ownership Structure on Corporate Governance}

In our study on the influence of a bank's ownership structure on corporate governance, we wanted to find out how features like ownership concentration, foreign ownership, and state ownership influence corporate governance. When analyzing the correlation between ownership concentration and corporate governance the results show that banks with lower ownership concentration have a higher corporate governance index. This means that banks with more shareholders pay more attention to the disclosure of information related to corporate governance and trends in this field. We found a statistically significant and positive correlation between the number of shareholders and corporate governance index for the studied period in Latvia, Lithuania, Hungary, and Slovenia. A statistically significant and negative correlation was found only in Slovakia. The results show that, for most countries, consistent with our expectations that lower ownership concentration has a positive effect on corporate governance. Ownership concentration can also be defined with the number of large shareholders; in this case, the results show that, in connection with the corporate governance index, correlations are not significant in most surveyed countries. A statistically positive correlation was identified in Latvia and in Hungary, a significant and negative correlation was identified in Slovakia. The variable regarding the number of large shareholders does not have a significant influence on explaining the influence of ownership concentration or ownership structure on the corporate governance index. Contrary to the research results regarding the correlation between the number of large shareholders and corporate governance, the correlation between shareholder ownership share (for owners with more than $5 \%$ shares) and corporate governance index, the results were more satisfactory, as they show a statistically significant and negative correlation in Latvia, Lithuania and in Slovenia. In other countries, the correlation is positive, but not significant. The results conform to our expectations for the surveyed countries, according to which a higher degree of ownership concentration for shareholders with more than $5 \%$ of shares correlates with poorer corporate governance. Because a statistically significant correlation was found in most cases as having a positive relationship with corporate governance, we confirmed a partial hypothesis that lower ownership concentration (diversified ownership) has a positive correlation with a higher corporate governance index. Love and Rachinsky (2007) also found that banks with high ownership concentration have considerably worse corporate governance. Erkens et al. (2012) also found that companies with a higher degree of institutionalized ownership perform poorly. On the other hand, Magalhaes et al. (2010) found out that a concentrated ownership structure enables more efficient supervision, and consequently, better company performance. Denis and McConnell (2003) also found out that large shareholders can use their power and are more likely to make decisions, which will increase the value for shareholders. On the other hand, diversified ownership and small shareholders demonstrate less power and incentive to influence the decision-making process. Caprio et al. (2007) found that concentrated ownership represents an important bank governance mechanism. Li and Song (2010) also found that higher ownership concentration increases bank value. Lskavyan and Spatareanu (2006) found that ownership concentration does not have an important impact on performance, both in developed countries and transitional economies. Based on the findings of previous research, it can be confirmed that there is no single answer to the question regarding bank performance concerning the higher or lower level of ownership concentration.

Regarding the correlation between foreign ownership and corporate governance index, there is a positive correlation, except for Slovenia, which is statistically significant in the Czech Republic, Slovakia, and Hungary. It can be 
concluded that the greater the foreign ownership share the better the corporate governance. This means that our partial hypothesis, according to which foreign ownership has a positive effect on corporate governance, can be confirmed. On the other hand, Love and Rachinsky (2007) found that there is no statistically significant correlation between foreign ownership and corporate governance. The results of some research show that there is a positive and significant correlation between foreign ownership and bank performance (e.g. Choi and Hasan (2005), Tandelilin et al. (2007), Barako and Tower (2007)). On the other hand, the findings of Lensink and Naaborg (2007), show that an increase in foreign ownership has a negative influence on the bank performance (particularly on net interest margin and profit).

The research results regarding the correlation between state ownership and corporate governance show that only Slovakia has a statistically significant and negative correlation between state ownership and the value of corporate governance index. In Slovenia, this correlation is positive and statistically significant. For many surveyed countries we could not prove that state ownership has a statistically negative correlation with corporate governance. Love and Rachinsky (2007) found that there is no statistically significant correlation between state ownership and corporate governance. The results found in previous research in the field of company performance showed that state ownership was mainly negatively correlated with performance (e.g. Megginson, Nash \& Van Randenborgh, 1994; Majumdar, 1998; Boubakri \& Cosset, 1998; Claessens \& Djankov, 1999; Dewenter \& Malatesta, 2001; Barako \& Tower, 2007; Cornett et al., 2010). In state-owned enterprises, board members were powerless decision-makers, as the decision-making process in the boardroom was controlled by the government and politicians (Apriliyanti \& Randøy, 2018).

Based on our research, we confirmed that bank ownership structure had an impact on corporate governance. Indirectly, this means that a bank's ownership structure affects the relationship between corporate governance and bank performance. More diversified ownership and a higher level of foreign ownership had a positive correlation to the corporate governance index (see also, Zsámboki, 2006). On the other hand, the correlation between state ownership and corporate governance index was not clear.

\section{Conclusion}

The results of our empirical analysis for the sample of countries showed that smaller ownership concentration and foreign ownership have a positive influence on corporate governance. We cannot say with certainty, however, that state ownership had a negative influence on corporate governance and, subsequently, on bank performance. We cannot reject the hypothesis, nor even prove it that state ownership had a negative influence on corporate governance in the sense of banking results.

According to a large body of research, corporate governance had a central role in the economic crisis and was also an important factor that should be thoroughly studied in the future in the context of company performance. It may at first appear that corporate governance depends on certain factors and that its impact on corporate governance is obvious, but there are many unexplored areas in this field of research. By using relevant and comparable data and appropriate methodological approaches in the future, many of these unanswered questions can be solved.

The crisis raised many questions for the political and professional public, ranging from bank recovery, regulation, supervision efficiency, management, and supervisory board responsibility. Preventing poor banking practices does not lie only in controlling functions, but also in general corporate culture, risk-taking culture, ethical culture, and in the social perception of the functions and managerial roles, regardless of ownership structure. 


\section{References}

Adams, R., \& Mehran, H. (2003). Is corporate governance different for bank holding companies? Federal Reserve Bank of New -142. DOI: https://papers.ssrn.com/sol3/papers.cfm?abstract_id=387561

Aljifri, K., \& Moustafa, M. (2007). The Impact of Corporate Governance Mechanisms on the Performance of UAE Firms: An Empirical Analysis. Journal of Economic \& Administrative Sciences, 23(2), 71-93. DOI: https://www.emerald.com/insight/content/ doi/10.1108/10264116200700008/full/html

Andrle, M., Brada, J. C., Tomšík, V., and Vlček, J. (2019). Banks’ Adjustment to Basel III Reform: A Bank-Level Perspective for Emerging Europe. Eastern European Economics, 57(1), 50-69. DOI: 10.1080/00128775.2018.1483202

Apriliyanti, I. D. and Randøy, T. (2018). Between Politics and Business: Boardroom Decision Making in State-Owned Indonesian Enterprises. Corporate Governance, An International Review, 27(3), 166-185. DOI: https://onlinelibrary.wiley.com/doi/10.1111/ corg. 12270

Barako, D., \& Tower, G. (2007). Corporate Governance and Bank Performance: Does Ownership Matter? Evidence from the Kenyan Banking Sector. Corporate Ownership and Control, 4(2), 133-145. DOI: http://virtusinterpress.org/IMG/pdf/10-22495_cocv4i2p13. pdf

Basel Committee on Banking Supervision. (2010, October 7). Principles for Enhancing Corporate Governance. Bank for International Settlements. Retrieved from http://www.bis.org/publ/bcbs176.pdf

Becht, M., Bolton, P., \& Röell, A. (2002, October 31). Corporate Governance and Control. Retrieved from http://papers.ssrn.com/sol3/ papers.cfm?abstract_id $=343461$

Boubakri, N., \& Cosset, J.-C. (2002). The Financial and Operating Performance of Newly Privatized Firms: Evidence from Developing Countries. The Journal of Finance, 53(3), 1081-1110. DOI: https://doi.org/10.1111/0022-1082.00044

Brůna, K., Blahová, N. (2019). Constraints in the Supply of Credit in an Open Transition Economy under New Basel III Requirements: The Case of the Czech Republic. Eastern European Economics, 57(1), 70-85. DOI: 10.1080/00128775.2018.1496457

Burkart, M., \& Panunzi, F. (2006). Agency Conflicts, Ownership Concentration, and Legal Shareholder Protection. Journal of Financial Intermediation, 15(1), 1-31. DOI: https://doi.org/10.1016/j.jfi.2004.12.004

Caprio, G., Laeven, L., \& Levine, R. (2007). Governance and Banks Valuations. Journal of Financial Intermediation, 16(4), $584-617$. DOI: 10.1016/j.jfi.2006.10.003

Choi, S., \& Hasan, I. (2005). Ownership, Governance, and Bank Performance: Korean Experience. Financial Markets, Institutions \& Instruments, 14(4), 215-242. DOI: https://doi.org/10.1111/j.0963-8008.2005.00104.x

Choudhry, M. (2011). Effective Bank Corporate Governance: Observations from the Market Crash and Recommendations for Policy. Journal of Applied Finance and Banking, 1(1), 179-211. DOI: http://www.scienpress.com/upload/JAFB/Nol\%201_1_9.pdf

Claessens, S., \& Djankov, S. (1999). Ownership Concentration and Corporate Performance in the Czech Republic. Journal of Comparative Economics, 27(3), 498-513. DOI: https://ideas.repec.org/a/eee/jcecon/v27y1999i3p498-513.html

Cornett, M., Guo, L., Khaksari, S., \& Tehranian, H. (2010). The Impact of State Ownership on Performance Differences in Privately-Owned Versus State-Owned Banks: An International Comparison. Journal of Financial Intermediation, 19(1), 74-94. DOI: https://doi.org/10.1016/j.ji.2008.09.005

Dahya, J., Dimitrov, O., \& McConnell, J. (2008). Dominant Shareholders, Corporate Boards and Corporate Value: A Cross-Country Analysis. Journal of Financial Economics, 87(1), 73-100. DOI: https://doi.org/10.1016/j.jfineco.2006.10.005

Dittmar, A., Mahrt-Smith, J., \& Servaes, H. (2003). International Corporate Governance and Corporate Cash Holdings. Journal of Financial and Quantitative Analysis, 38(1), 111-133.

Denis, D. (2001). Twenty-Five Years of Corporate Governance Research and Counting. Review of Financial Economics, 10(3), $191-212$. DOI: https://doi.org/10.1016/S1058-3300(01)00037-4

Denis, D., \& McConnell, J. (2003, January 31). International Corporate Governance. ECGI Working Paper Series in Finance, Working Paper No. 02/2003. Retrieved from http://papers.ssrn.com/sol3/papers.cfm?abstract_id=320121

Dewenter, K., \& Malatesta, P. (2001). State-Owned and Privately Owned Firms: An Empirical Analysis of Profitability-, Leverage, and Labor Intensity. American Economic Review, 91(1), 320-334. DOI: 10.1257/aer.91.1.320

Durnev, A., \& Kim, E. (2005). To Steal or Not to Steal: Firm characteristics, legal environment, and valuation. Journal of Finance, 60(3), 1461-1493.

Erkens, D., Hung, M., \& Matos, P. (2012). Corporate Governance in the 2007-2008 Financial Crisis: Evidence from Financial Institutions Worldwide. Journal of Corporate Finance, 18(2), 389-411. DOI: https://doi.org/10.1016/j.jcorpfin.2012.01.005

European Commission. (2010a, May 31). The Green Book: Corporate Governance of Financial Institutions and Income Policy (Zelena knjiga: Korporativno upravljanje finančnih institucij in politika prejemkov.) Retrieved from http://eur-lex.europa.eu/LexUriServ/ LexUriServ.do?uri=COM:2010:0284:FIN:SL:PDF

European Commission. (2010b, June 2). Corporate Governance in Financial Institutions: Lessons to be Drawn from the Current Financial Crisis, Best Practises, COM (2010) 284. Retrieved from http://www.microfinancegateway.org/sites/default/files/mfg-enpaper-corporate-governance-in-financial-institutions-lessons-to-be-drawn-from-the-current-financial-crisis-best-practicesjun-2010.pdf 
Fidrmuc, J., Kapounek, S. (2019). The Risks and Financial Vulnerability of Foreign Bank Ownership in CEECs: Evidence from Exchange Rate Depreciation after the Financial Crisis. Eastern European Economics, 58(1), 34-48 DOI: 10.1080/00128775.2019.1666412

Firoozi, M., M. Magnan, S. Fortin. (2018). Does Proximity to Corporate Headquarters Enhance Directors' Monitoring Effectiveness? A Look at Financial Reporting Quality. Corporate Governance, An International Review, 27(2), 98-119. DOI: https://doi. org/10.1111/corg.12264

Francis, B., Hasan, I., \& Wu, Q. (2013, May 20). The Benefits of Conservative Accounting to Shareholders: Evidence from the Financial Crisis. Bank of Finland Research Discussion Paper No. 8/2013. Retrieved from http://papers.ssrn.com/sol3/papers.cfm?abstract_ id=2291352

Frydman, R., Gray, C., Hessel, M., \& Rapaczynsk, A. (1999). When Does Privatization Work? The Impact of Private Ownership on Corporate Performance in Transition Economies. Quarterly Journal of Economics, 114(4), 1153-1191. DOI: https://doi. org/10.1162/003355399556241

Gillan, S., Hartzell, J., \& Starks, L. (2007). Tradeoffs in Corporate Governance: Evidence from Board Structures and Charter Provisions. Retrieved from http://www.law.yale.edu/documents/pdf/CBL/starks_paper.pdf.

Himmelberg, C., Hubbard, R., \& Love, I. (2002). Investment, Protection, Ownership, and the Cost of Capital. Retrieved from National Bank of Belgium: http://www.nbb.be/doc/oc/repec/reswpp/WP25.pdf.

Hughes, J., \& Mester, L. (2010). Efficiency in Banking: Theory, Practice, and Evidence. In A. Berger, J. Wilson, \& P. Molyneux (Edit.), The Oxford Handbook of Banking ( $2^{\text {nd }}$ ed., p. 463-485). New York: Oxford University Press.

Jensen, M. (1993). The Modern Industrial Revolution, Exit, and the Failure of Internal Control Systems. The Journal of Finance, 48(3), 831-880. DOI: https://doi.org/10.1111/j.1540-6261.1993.tb04022.x

Košak, M., Zajc P. \& Zorić J. (2009). Bank Efficiency Differences in the New EU Member States. Baltic Journal of Economics, 9(2), 67-89, DOI: 10.1080/1406099X.2009.10840462

Kyereboah-Coleman, A., \& Biekpe, N. (2006). Do Boards and CEOs Matter for Bank Performance? A Comparative Analysis of Banks in Ghana. Corporate Ownership and Control, 4(1), 119-126. DOI: 10.22495/cocv4i1p10

Lensink, R., \& Naaborg, I. (2007). Does Foreign Ownership Foster Bank Performance? Applied Financial Economics, 17(11), $881-885$. DOI: https://doi.org/10.1080/09603100600827653

La Porta, R., Lopez-de-Silanes, F., \& Shleifer, A. (2002). Government ownership of commercial banks. The Journal of Finance, 57(1), 265-301.

La Porta, R., Lopez-de-Silanes, F., Shleifer, A., \& Vishny, R. (1997). Legal Determinants of External Finance. Journal of Finance, 52(3), 1131-1150.

La Porta, R., Lopez-de-Silanes, F., Shleifer, A., \& Vishny, R. (1998). Law and Finance. Journal of Political Economy, $106(6), 1113$-1155.

Li, L., \& Song, F. (2010,July 9). Corporate Governance, Regulation, and Bank Performance: A Cross-country Analysis. Retrieved from http:// www.researchgate.net/publication/228455990_Corporate_Governance_Regulation_and_Bank_Performance_A_Cross-country_ Analysis

Love, I., \& Rachinsky, A. (2007). Corporate Governance, Ownership, and Bank Performance in Emerging Markets: Evidence from Russia and Ukraine. Emerging Markets Finance and Trade, 51(2), 101-121. DOI: 10.1080/1540496X.2014.998945

Lskavyan, V., \& Spatareanu, M. (2006). Ownership Concentration, Market Monitoring, and Performance: Evidence from the UK, the Czech Republic and Poland. Journal of Applied Economics, 9(1), 91-104. DOI: https://ideas.repec.org/p/run/wpaper/2005-012. html

Magalhaes, R., Gutiérrez, M., \& Tribo, J. (2010, March 3). Banks' Ownership Structure, Risk and Performance. Retrieved from http:// papers.ssrn.com/sol3/papers.cfm?abstract_id=1102390

Mahoney, P., \& Mei, J. (2009, February 28). Mandatory vs. Contractual Disclosure in Securities Markets: Evidence From The 1930s. Retrieved from http://papers.ssrn.com/sol3/papers.cfm?abstract_id=883706

Majumdar, S. (1998). Assessing Comparative Efficiency of the State-Owned Mixed and Private Sectors in Indian Industry. Public Choice, 24(1/2), 1-24. DOI: https://link.springer.com/article/10.1023/A:1004941023587

Megginson, W., Nash, R., \& Randenborgh, M. (1994). The Financial and Operating Performance of Newly Privatized Firms: An International Empirical Analysis. Journal of Finance, 49(2), 403-452. DOI: https://doi.org/10.1111/j.1540-6261.1994.tb05147.x

Maripuu, P. \& Männasoo K. (2014). Financial Distress and Cycle-Sensitive Corporate Investments. Baltic Journal of Economics, 14(12), 181-193. DOI: 10.1080/1406099X.2014.999481

Millar, C., Eldomiaty, T., Choi, C., \& Hilton, B. (2005). Corporate Governance and Institutional Transparency in Emerging Markets. Journal of Business Ethics, 59(1-2), 163-174. DOI: https://link.springer.com/article/10.1007/s10551-005-3412-1

Organisation for Economic Co-operation and Development. (2009, June 8). Principles of Corporate Governance by OECD. (Načela korporativnega upravljanja OECD). Retrieved from http://www.oecd.org/daf/ca/corporategovernanceprinciples/42485839.pdf

Pascual-Fuster, B. and R. Crespí-Cladera. (2018). Politicians in the Boardroom: Is it a Convenient Burden? Corporate Governance, an International Review 26(6), 448-470. DOI: https://doi.org/10.1111/corg.12261

Ribnikar, A. (2009). Anti-Crisis Legislation-Excessive Intervention in Corporate Governance? (Protikrizna zakonodaja - pretiran poseg v korporacijsko upravljanje?) Bančni vestnik, 34 (7-8), 43-47. 
Schleifer, A., \& Vishny, R. (1997). A Survey of Corporate Governance. The Journal of Finance, 52(2), 737-783. DOI: https://doi. org/10.1111/j.1540-6261.1997.tb04820.x

Słomka-Gołębiowska, A., \& Urbanek, P. (2014). Executive Remuneration Policy At Banks in Poland After The Financial Crisis - Evolution or Revolution? Comparative Economic Research, 17(2), 25-44. DOI: https://doi.org/10.2478/cer-2014-0012

Spong, K., \& Sullivan, R. (2007, August 31). Corporate Governance and Bank Performance. Federal Reserve Bank of Kansas City. Retrieved from https://papers.ssrn.com/sol3/papers.cfm?abstract_id=1011068

Tandelilin, E., Kaaro, H., \& Mahadwartha, P. (2007, April 19). Corporate Governance, Risk Management, and Bank Performance: Does Type of Ownership Matter? EADN Working Paper No. 34. Retrieved from http://www.eadn.org/eduardus.pdf

Zsámboki, B. (2006, August 3). Impact of Foreign Ownership on the Banking Sector: the Hungarian Experience. Retrieved from http:// www.oecd.org/cfe/leed/37051210.pdf

Wen, W. (2010, December 6). Ownership Structure and Bank Performance in China: Does Ownership Concentration Matter? Retrieved from http://papers.ssrn.com/sol3/papers.cfm?abstract_id=1747655

\section{Pomen korporativnega upravljanja bank, povezanega z lastništvom v mednarodnem okolju}

\section{Izvleček}

Analiza dejavnikov korporativnega upravljanja je razdeljena na štiri tematske sklope. V prvem delu korporativno upravljanje opredeljujemo kot del širšega gospodarskega okvira. Drugi del obravnava načela korporativnega upravljanja. V tretjem delu opredeljujemo in ocenjujemo razmerje med indeksom korporativnega upravljanja in posameznimi kazalniki (kazalnik zavezanosti, preglednosti in razkrivanja, skrb za partnerje ter nadzor in revizija) glede lastništva. Analiza je narejena za države Srednje in Vzhodne Evrope. Višja raven tujega lastništva ima pozitivno korelacijo z indeksom korporativnega upravljanja podjetij, na drugi strani pa povezava med državnim lastništvom in indeksom korporativnega upravljanja ni jasna. Preprečevanje slabih bančnih praks ni le v nadzornih funkcijah, temveč tudi v splošni korporacijski kulturi, kulturi prevzemanja tveganj in kulturi ter družbenem dojemanju vodstvenih položajev ne glede na lastniško strukturo.

Ključne besede: indeks korporativnega upravljanja, državno lastništvo, lastniška struktura, načela korporativnega upravljanja, neodvisnost uprave 